\title{
Analisis Faktor-Faktor Pemilihan Lokasi Markas Komando Terhadap Keberhasilan Teritorial Pada Suatu Wilayah Teritori X
}

\author{
Frejohn da Costa ${ }^{1 *}$, Antonius Widyoutomo ${ }^{1}$ \\ ${ }^{1}$ Sekolah Staf dan Komando Angkatan Laut (SESKOAL) \\ J. Ciledug Raya No 2, Kompleks Seskoal Kebayoran Lama Kota Jakarta \\ *frejohn49@gmail.com \\ DOI: https://doi.org/10.21107/rekayasa.v14i2.10999
}

\begin{abstract}
ABSTRAK
Markas Komando adalah sebuah tempat yang digunakan sebagai tempat kedudukan pemimpin tentara (pandu, badan perjuangan) untuk memberi perintah, memimpin suatu pasukan. Penulisan ini dimaksudkan untuk mengidentifikasi dan menganalisis faktor-faktor pemilihan lokasi Markas Komando terhadap keberhasilan teritorial pada suatu daerah teritori X. Secara khusus menganalisis apakah terdapat dampak signifikan antara faktor kedekatan infrastruktur ( $\left.X_{1}\right)$, lingkungan pemerintah daerah $\left(\mathrm{X}_{2}\right)$ dan anggaran terhadap keberhasilan teritorial $\left(X_{3}\right)$. Metode analisis data penelitian ini merupakan analisis regresi linier berganda. Hasil penelitian menunjukkan bahwa kedekatan dengan infrastruktur, lingkungan pemerintah daerah, dan alokasi anggaran berpengaruh signifikan terhadap keberhasilan Markas Komando $(Y=0,145+$ $\left.0,327 X_{2}+0,272 X_{1}+0,398 X_{3}\right)$. Berdasarkan hasil uji t, variabel kedekatan dengan infrastruktur berpengaruh signifikan terhadap keberhasilan markas komando.
\end{abstract}

Keywords : teritorial, markas komando, regresi linear berganda

\section{PENDAHULUAN}

Pemilihan lokasi pada suatu kemarkasan atau Markas Komando akan mempengaruhi risiko dan keberhasilan Markas Komando tersebut secara keseluruhan, mengingat lokasi sangat mempengaruhi anggaran tetap maupun anggaran variabel, baik dalam jangka menengah maupun jangka panjang (Cheng dan Lin, 2002). Adanya perbedaan keberhasilan kemarkasan-kemarkasan dan perbedaan kekuatan atau kelemahan kemarkasan, sering karena faktor-faktor lokasi. Dalam situasi persaingan, factor-faktor lokasi dapat menjadi faktor-faktor kritis yang membuatnya sangat penting, agar Markas Komando yang dijalankan dapat bersaing secara efektif, lokasi Markas Komando haruslah strategis dan mudah dijangkau (Saaty, 2008).

Banyak faktor yang menentukan keberhasilan suatu Markas Komando, diantaranya faktor tersebut adalah ketepatan pemilihan lokasi. Ketepatan pemilihan lokasi merupakan salah satu faktor yang dipertimbangkan oleh seorang pimpinan sebelum mendirikan Markas

\section{Article History:}

Received: May, 15 $5^{\text {th }}$ 2021; Accepted: July, $31^{\text {st }} 2021$

Rekayasa ISSN: $2502-5325$ has been Accredited by Ristekdikti (Arjuna) Decree: No. 23/E/KPT/2019 August 8th, 2019 effective until 2023
Komandonya. Hal ini terjadi karena pemilihan lokasi yang tepat seringkali menentukan keberhasilan suatu Markas Komando. Oleh sebab itu berlaku untuk Markas Komando karena Markas Komando diharuskan untuk tingkat hubungan yang selaras bersama dengan penggunanya (Badri, 2001). Markas-markas Komando harus lebih bermanfaat bagi penggunanya sehingga bermanfaat bagi yang memanfaatkanya (Anggraini dan Sihotang, 2019).

Bagi Markas Komando, lokasi yang strategis seringkali lebih penting dari pada faktor-faktor yang lain (Defne, 2011). Oleh sebab itu Markas Komando rela mengeluarkan anggaran yang banyak untuk pemilihan lokasi yang tepat. Seperti halnya pada Markas Komando yang berdiri disekitar Wilayah Teritori tersebut, karena Wilayah Teritori di Daerah X berada di pusat kota. Mereka rela mengeluarkan anggaran yang besar untuk membuka Markas Komando dilokasi ini dengan mengharapkan keberhasilan teritorial yang besar mengingat adanya wilayah teritori yang potensial di Daerah X. Disamping faktor anggaran, faktor

\section{Cite this as:}

Da Costa, F \& Widyoutomo, A. (2021). Analisis Faktor-Faktor Pemilihan Lokasi Markas Komando Terhadap Keberhasioan Teritorial pada Suatu Wilayah Teritori X. Rekayasa 14 (2). 258262. doi: https://doi.org/10.21107/rekayasa.v14i2. 10999. (c) 2021 Frejohn Da Costa 
kedekatan dengan lingkungan pemerintah daerah merupakan hal-hal yang diperhatikan Markas Komando sebelum mendirikan Markas Komando pada areal X. Faktor pemilihan lokasi Markas Komando tidak hanya didasarkan pada faktor kedekatan dengan target kawasan teritori dan ketersediaan infrastruktur, terdapat faktor-faktor lainnya yang menjadi pertimbangan Markas Komando pada areal $X$ dalam memilih dan menentukan lokasi uasahanya yang pada akhirnya dapat menghantarkan Markas Komando tersebut pada keberhasilan.

\section{METODE PENELITIAN}

Memilih lokasi Markas Komando terdekat dengan target wilayah teritori merupakan salah satu strategi pemerintah daerah selain itu juga memudahkan koordinasi dalam mengakomodir perintah yang diberikan (Trivedi, 2016). Selain kedekatan dengan target wilayah teritorinya, ketersediaan infrastruktur yang memadai juga harus dianalisa dalam pemilihan lokasi Markas Komando. Bagi suatu Markas Komando Instansi A dan Instansi B ketersediaan listrik merupakan hal pokok bagi jalannya kelancaran kegiatan teritorialnya. Faktor pemilihan lokasi Markas Komando tidak hanya didasarkan pada faktor kedekatan dengan target kawasan teritori dan ketersediaan infrastruktur, terdapat faktor-faktor lainnya yang menjadi pertimbangan Markas Komando pada areal $\mathrm{X}$ dalam memilih dan menentukan lokasi uasahanya yang pada akhirnya dapat menghantarkan Markas Komando tersebut pada keberhasilan.

Analisis lokasi disektor industri terfokus pada minimalisasi anggaran, sementara fokus pada sektor ditujukan untuk memaksimalkan keberhasilan teritorial. Semua dikarenakan Markas Komando manufaktur mendapati anggaran cenderung sangat berbeda diantara lokasi-lokasi yang berbeda, sementara Markas Komando mendapati lokasi sering lebih berdampak terhadap keberhasilan teritorial daripada anggaran. Bagi Markas Komando merupakan kawasan strategis sering kali lebih mempengaruhi keberhasilan teritorial daripada mempengaruhi anggaran. Disampaikan juga bahwa fokus lokasi bagi Markas Komando seharusnya adalah pada volume pemerintah daerah dan keberhasilan teritorial.

\section{HASIL DAN PEMBAHASAN}

Tabel 1 Menunjukkan keempat variabel yang telah diteliti bahwa nilai alpha di atas 0.6 , sehingga seluruh variabel yang dihitung adalah reliabel dan tahap analisis selanjutnya bisa digunakan. Nilai signifikan ketiga variabel $X_{1}, X_{2}$, dan $X_{3}$ lebih besar dari 0.05 , hal ini menunjukan bahwa tidak terjadi heteroskedastisitas pada model regresi yang dibuat.

Tabel 1. Hasil Uji Validitas dan Reliabilitas

\begin{tabular}{ccc}
\hline Variabel & Cronbach Alpha & Keterangan \\
\hline X1 & 0.638 & Reliabel \\
X2 & 0.659 & Reliabel \\
X3 & 0.616 & Reliabel \\
Y & 0.642 & Reliabel \\
\hline
\end{tabular}

$\mathrm{X}_{1}$ : kedekatan dengan infrastruktur

$\mathrm{X}_{2}$ : lingkungan pemerintah daerah

$\mathrm{X}_{3}$ : anggaran lokasi

$Y$ : tingkat keberhasilan markas komando

Tabel 2. Hasil Uji Heteroskedastisitas

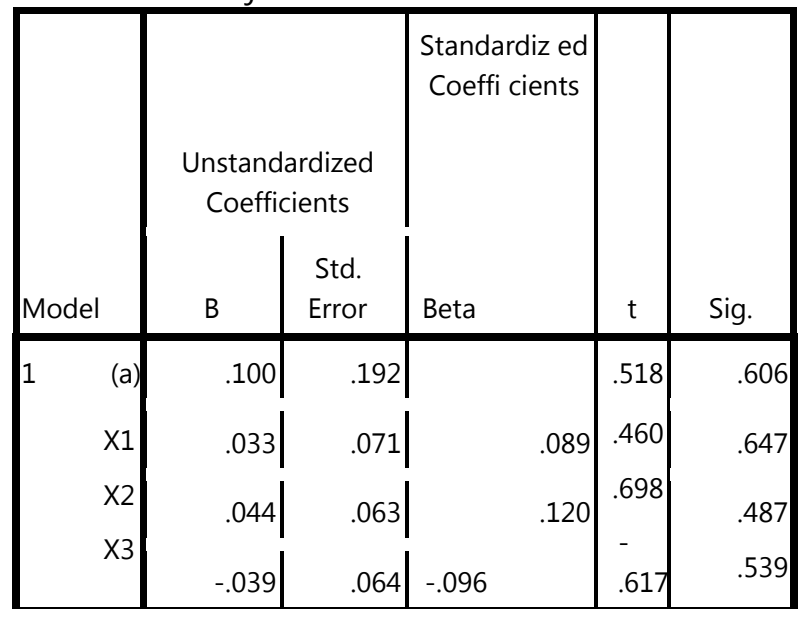

Tabel 3. Hasil Uji Multikolinearitas

\begin{tabular}{|l|c|c|}
\hline Model & Tolerance & VIF \\
\hline $\mathrm{X}_{1}$ & .360 & 2.779 \\
\hline $\mathrm{X}_{2}$ & .456 & 2.192 \\
\hline $\mathrm{X}_{3}$ & .551 & 1.815 \\
\hline
\end{tabular}

Hasil uji multikolinearitas pada Tabel 3 maka dapat dilihat bahwa nilai Variation Inflation Factor (VIF) secara berturutturut 2.779, 2.192, 1.815 yang berarti nilai Variation Inflation Factor (VIF) seluruhnya bekisar dibawah angka 10 atau $\mathrm{VH}<10$ yang artinya pada variabel-variabel bebas pada data penelitian yang akan dilakukan ini tidak terjadi gejala-gejala multikolinearitas. 
Tabel 4. Hasil Regresi Linear Berganda

\begin{tabular}{|c|c|c|c|c|c|}
\hline \multirow[t]{2}{*}{ Model } & \multicolumn{2}{|c|}{$\begin{array}{l}\text { Unstandardized } \\
\text { Coefficients }\end{array}$} & \multicolumn{2}{|c|}{$\begin{array}{c}\text { Standardized } \\
\text { Coefficients }\end{array}$} & \multirow{2}{*}{$\begin{array}{l}\text { Sig } \\
\text { Sig }\end{array}$} \\
\hline & B & $\begin{array}{l}\text { Std } \\
\text { Error }\end{array}$ & Beta & $\mathrm{t}$ & \\
\hline (a) & .145 & .292 & & .498 & .620 \\
\hline$X_{1}$ & .272 & .107 & .272 & 2.529 & .014 \\
\hline$X_{2}$ & .327 & .096 & .326 & 3.404 & .001 \\
\hline$X_{3}$ & .398 & .097 & .359 & 4.123 & .000 \\
\hline
\end{tabular}

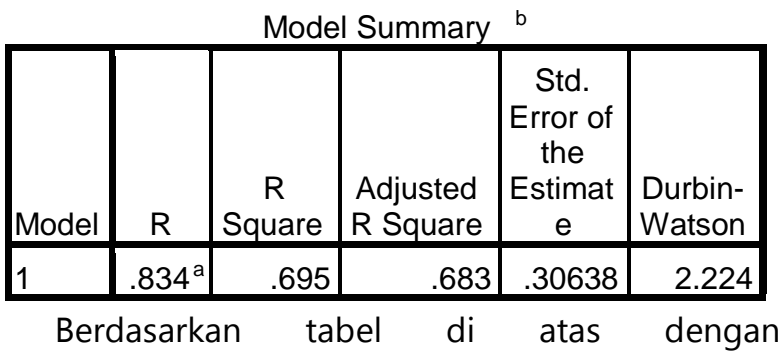

menggunakan Unstandardized Coefficients, hasil analisis regresi linier berganda dapat ditulis dalam persamaan berikut: $Y=0,145+0,272 X_{1}+0,327 X_{2}$ $+0,398 X_{3}$. Berdasarkan persamaan tersebut tampak masing-masing variabel independen memiliki koefisien regresi dengan tanda positif $(+)$, artinya kenaikan variabel independen akan diikuti oleh kenaikan variabel dependen. Dari tabel di atas dapat dijelaskan bahwa konstanta tanpa ada kedekatan dengan infrastruktur, lingkungan pemerintah daerah dan anggaran lokasi memiliki pengaruh walaupun kecil dengan nilai beta 0,145. Dengan nilai beta sebesar 0,272, Variabel kedekatan dengan infrastuktur memiliki pengaruh cukup besar. Variabel lingkungan pemerintah daerah memiliki pengaruh yang besar dengan nilai beta 0,327, dan varibel anggaran lokasi berpengaruh paling besar dengan nilai beta 0,398. Hasil uji $t$ pada tabel diatas memiliki variabel independen yang pengaruh signifikan terhadap variabel dependen. Berikut adalah penjelasan tabel diatas:

1. Variabel kedekatan dengan infrastruktur memiliki probabilitas signifikan 0,014, karena probabilitas signifikannya kurang dari $5 \%(0,014$ $<0,05)$ bisa disebutkan bahwa variabel kedekatan dengan infrastruktur secara parsial berpengaruh posotif dan signifikan terhadap keberhasilan Markas Komando.

2. Variabel lingkungan pemerintah daerah memiliki probabilitas signifikan 0,001, karena probabilitas signifikannya kurang dari $5 \%(0,001$ $<0,05)$ hal ini menjelaskan bahwa variabel lingkungan pemerintah daerah secara parsial berpengaruh positif dan signifikan terhadap keberhasilan Markas Komando.

3. Variabel anggaran lokasi memiliki probabilitas signifikan 0,000, karena probabilitas signifikannya kurang dari $5 \%(0,000<0,05)$ maka disimpulkan bahwa variabel anggaran lokasi secara parsial berpengaruh positif dan signifikan terhadap keberhasilan Markas Komando.

Tabel 5. Hasil Uji ANOVA

\begin{tabular}{|l|r|r|r|l|l|}
\hline Model & \multicolumn{1}{|c|}{$\begin{array}{l}\text { Sum of } \\
\text { Squares }\end{array}$} & df & $\begin{array}{l}\text { Mean } \\
\text { Square }\end{array}$ & F & Sig. \\
\hline Regression & 15.650 & 3 & 5.217 & 55.571 & $.000^{\mathrm{a}}$ \\
\hline Residual & 6.853 & 73 & .094 & & \\
\hline Total & 22.502 & 76 & & & \\
\hline
\end{tabular}

Berdasarkan hasil uji ANOVA atau uji $\mathrm{F}$ pada tabel 5.8 memiliki probabilitas signifikan 0,000 , karena probabilitas signifikannya kurang dari $5 \%$ $(0,000<0,05)$ maka disimpulkan bahwa variabel kedekatan dengan infrastuktur, lingkungan pemerintah daerah, dan anggaran lokasi berpengaruh secara signifikan terhadap variabel keberhasilan Markas Komando (Y). Hasil diatas tampak bahwa besarnya $R^{2}$ adalah 0.695 . Hal ini berarti bahwa 69,5\% variasi keberhasilan Markas Komando dapat dijelaskan oleh variasi dari ketiga variabel independen yakni kedekatan dengan infrastruktur, lingkungan Pemerintah daerah, dan Anggaran Lokasi, sedangkan 30,5\% lainnya dijelaskan oleh sebab-sebab lain di luar model.

Berdasarkan hasil analisis regresi diperoleh koefisien regresi untuk variabel $X_{1}$ yaitu $b_{1}$ sebesar 0,272 dengan signifikansi 0,014 . Dengan demikian dapat dijelaskan bahwa variabel kedekatan dengan infrastruktur $X_{1}$ dipengaruhi tingkat positif dan signifikasi terhadap keberhasilan Markas Komando (Y). Dapat dijelaskan bahwa pengaruh variabel $X_{1}$ terhadap variabel $Y$ adalah searah dan bermakna. Dimana setiap variabel $X_{1}$ meningkat, maka akan diikuti peningkatan variabel $Y$, sebaliknya juga gitu. Variabel kedekatan dengan infrastruktur adalah hal pertimbangan pemilik dalam memilih lokasi Markas Komando. Kedekatan dengan infrastruktur penting dipertimbangkan oleh pengMarkas Komando dalam memilih lokasi Markas Komandonya, karena infrastruktur tersebut merupakan penunjang jalannya kegiatan pemerintah daerah, Selain itu, kedekatan dengan infrastruktur juga berpengaruh terhadap keberhasilan Markas Komando. Berdasarkan hasil analisis regresi diperoleh koefisien regresi untuk variabel $X_{2}$ yaitu $b_{2}$ sebesar 0,327 dengan 
signifikansi 0,001. Dengan demikian dapat dijelaskan bahwa variabel lingkungan pemerintah daerah $\mathrm{X}_{2}$ keberhasilan Markas Komando dipengaruhi nilai positif dan signifikan terhadap $(Y)$. Sehingga pengaruh variabel $X_{2}$ terhadap variabel $Y$ adalah searah dan bermakna. Dimana setiap variabel $\mathrm{X}_{2}$ meningkat, maka akan diikuti peningkatan variabel $Y$, demikian hal sebaliknya.

Pengaruh lingkungan pemerintah daerah terhadap keberhasilan Markas Komando dengan kata lain penelitian ini menjadi pertimbangan pemilik dalam menentukan lokasi Markas Komandonya. Misalnya, kedekatan dengan pemerintah daerah lain untuk menambah relasi Markas Komando dan saling bersinergi, kedekatan dengan konsumen yang merupakan target utama Markas Komando, kedekatan dengan pesaing untuk saling berkompetisi secara sehat dalam mengembangkan Markas Komando, perlunya kedekatan dengan supplier untuk menjaga kepercayaan, sehingga dapat mencapai keberhasilan Markas Komando yang diinginkan oleh pemilik. Oleh karena itu, perlunya pemilik Markas Komando mempertimbangkan lingkungan pemerintah daerah dalam menentukan lokasi Markas Komandonya. Sesuai dengan nilai analisis regresi diperoleh koefisien regresi untuk variabel $\mathrm{X}_{3}$ yaitu $b_{3}$ sebesar 0,398 dengan signifikansi 0,000. Dengan demikian dapat dijelaskan bahwa variabel anggaran lokasi $X_{3}$ sangat dipengaruhi keberhasilan Markas Komando $(\mathrm{Y})$. hal ini berarti pengaruh variabel $X_{3}$ terhadap variabel $Y$ adalah searah dan bermakna. Dimana setiap variabel $X_{3}$ meningkat, maka akan diikuti peningkatan variabel $Y$, begitu pula sebaliknya.

Variabel anggaran lokasi berdampak paling besar terhadap keberhasilan Markas Komando. Dapat ditunjukan meskipun anggaran yang harus dikeluarkkan untuk memperoleh tingkat strategisnya sebuah lokasi adalah mahal, pemilik Markas Komando tetap memilih lokasi tersebut karena letaknya yang dekat dengan konsumen, dekat dengan infrastruktur dan fasilitas-fasilitas lainnya, sehingga mendukung kelancaran jalannya kegiatan Markas Komando. Markas Komando yang dapat berjalan lancar maka akan dengan mudah mencapai keberhasilan. Namun pemilik harus tetap memeperhatikan anggaran untuk memperoleh lokasi yang strategis karena berhubungan dengan investasi awal Markas Komandonya.

\section{KESIMPULAN}

Penelitian ini mencoba untuk meneliti, apakah pemilihan lokasi Markas Komando berdasarkan faktor-faktor kedekatan dengan infrastruktur, lingkungan Pemerintah daerah, dan alokasi anggaran berpengaruh terhadap keberhasilan Markas Komando di sekitar Daerah X. Dengan memperhatikan hasil analisis dan pembahasan yang dilakukan sebelumnya, maka Hipotesis dari penelitian ini "dapat diterima". Beberapa kesimpulan penelitian ini sebagai berikut:

1. Bardasarkan hasil analisis regresi linier berganda, dapat dilihat bahwa tiap-tiap variabel independen memiliki koefisien regresi dengan tanda positif $(+)$, hal ini berarti setiap kenaikan variabel independen akan diikuti oleh kenaikan variabel dependen, begitu pula sebaliknya penurunan variabel independen akan diikuti oleh penurunan variabel dependen.

2. Berdasarkan hasil uji $t$, ketiga variabel independen yakni kedekatan dengan infrastruktur, lingkungan pemerintah daerah, dan anggaran lokasi secara farsial memiliki pengaruh yang signifikan terhadap variabel dependen keberhasilan Markas Komando. Demikian juga dengan hasil uji $F$, ketiga variabel independen secara bersama-sama berpengaruh secara signifikan terhadap variabel dependen.

3. Besarnya $R^{2}$ adalah 0.695 , hal ini berarti bahwa $69,5 \%$ variasi keberhasilan Markas Komando dapat dijelaskan oleh variasi dari ketiga variabel independen yakni kedekatan dengan infrastruktur, lingkungan Pemerintah daerah, dan alokasi anggaran, sedangkan 30,5\% variasi keberhasilan Markas Komando dipengaruhi oleh variabel lain yang tidak diteliti dalam penelitian ini.

4. Dari ketiga variabel independen yang diajukan dalam penelitian ini, variabel anggaran lokasi adalah variabel yang memiliki pengaruh paling besar terhadap Markas Komando yang berada di sekitar Daerah X.

\section{DAFTAR PUSTAKA}

Anggraini, \& Sihotang. (2019). Decision Support System For Choosing The Best Class Guardian With Simple Additive Weighting Method: Decision Support System For Choosing The Best Class Guardian With Simple Additive Weighting Method. Jurnal Mantik. 
Badri, M. A. (2001). A Combined AHP-GP Model For Quality Control Systems. International Journal of Production Economics, 72(1), 2740.

Cheng, C. H., \& Lin, Y. (2002). Evaluating The Best Main Battle Tank Using Fuzzy Decision Theory With Linguistic Criteria Evaluation. European Journal of Operational Research, 174-186.

Defne. (2011). Comparison of AHP and Fuzzy AHP for The Multicriteria Decision Making Process With Linguistic Evaluations. Journal of IstambulTicaret Universities.

Jaewook, L. (2010). A Hybrid Approach Of Goal Programming For Weapon Systems Selection. International Journal of Computers \& Industrial Engineering.

Kaliszewski, \& Podkopaev. (2016). Simple additive weighting-A Multiple Criteria Decision Analysis Methods. Expert Systems with Applications, 155-161.

Mastrocinque, E., Ramírez, F., Honrubia-Escribano, A., \& Pham, D. (2020). An AHP-Based MultiCriteria Model For Sustainable Supply Chain Development In The Renewable Energy
Sector. Expert Systems With Applications, 150, 1-17.

Ren-Shuai, \& Joseph. (2006). Selecting A Weapon System Using Zero-One Goal Programming And Analytic Network Process. Journal of Information and Optimization Sciences, 379399.

Saaty, T. L. (1993). "Pengambilan Keputusan Bagi para pemimpin, proses Hirarki Analitik untuk Pengambilan Keputusan Dalam Situasi Kompleks". Seri Manajemen No. 134. Jakarta: PT. Pustaka Binaman Pressindo.

Saaty, T. L. (2008). "Decision Making With The Analityc Hierarchy Process.". Int. J. Services Sciences, Vol.1.

Trivedi, A. (2016). A Hybrid Multi-Objective Decision Model For Emergency Shelter LocationRelocation Projects Using Fuzzy Analytic Hierarchy Process And Goal programming Approach. International Journal of Project Management.

Yavuz, \& Kılın. (2011). Weapon Selection Using The AHP And TOPSIS Methods Under Fuzzy Environment. Expert Systems With Applications, 8143-8151. 